\title{
The Analysis of the Efficiency of Digital Education Platforms Based on Various Variables
}

\author{
Elif Büşra YAZICI* \\ Classroom teaching, Ministry of Education ,Istanbul, Turkey \\ ORCID: 0000-0002-2213-9279
}

\author{
Mehmet Arif ÖZERBAŞ \\ Kırgızistan-Türkiye Manas Üniversitesi Edebiyat Fakültesi, Eğitim Bilimleri Bölümü, Gazi \\ Üniversitesi, Turkey \\ ORCID: 0000-0001-5354-1634
}

Article history

Received:

22.09.2021

Received in revised form: 08.12.2021

Accepted:

01.01.2022

Key words:

Digital education, digital platforms, platform efficiency level, design.
The present study aimed to determine the proficiencies of digital education platforms employed in mathematics courses instructed by classroom teachers based on various variables. For this purpose, the views of classroom teachers on the sub-dimensions of the Digital Education Platform Evaluation Scale (DEPES) were analyzed based on various variables. Correlational survey model was employed in the study. The study group included 601 classroom teachers employed in public and private primary schools in Istanbul during the 2020-2021 academic year. The Digital Education Platform Evaluation Scale (DEPES) was used in the study. SPSS 23 statistics software was utilized to analyze the study data. The differences between the paired variables were determined with the Mann-Whitney U-test, and the Kruskal-Wallis test was used to determine the differences between the other variables. The efficiency levels of the digital education platforms employed in primary school mathematics course were analyzed based on content, design, motivation, and teacher proficiency. The analysis of the views of the teachers on the efficiency of the digital education platforms based on the gender, seniority, age, education level, grade of instruction, school type, inservice training variables revealed significant differences between the scores of various platforms. It was determined that teachers who have seniority and age found EBA sufficient, less seniority and younger teachers found Okulistik sufficient. In general, the content of all platforms should be developed. The present study is considered important since the efficiency of digital education platforms frequently employed in the current learning and instruction processes was determined.

\section{Introduction}

Advances in science and technology changed access to information and affected the learning and instruction processes. Digital technologies are employed in current learning and

\footnotetext{
*Correspondency: elifyazici03@gmail.com
} 
instruction approaches. Digital technologies include applications that allow the electronic display, storage, and transmission of information (Cab1, 2015). Digital technologies, which could store unlimited data, have advanced at an unbelievable speed and became an indispensable requirement for humans. It is not possible to exclude digital technologies that became an indispensable element in people's lives from the educational life. Today, digital technologies are employed not only to access information but also in all dimensions of education. To improve educational environments, institutions, students, and teachers are required to utilize digital technologies effectively (Y1lmaz, 2020).

The utilization of digital learning and instruction technologies started with the FATIH Project in Turkey. FATIH Project, which was launched in 2010, is the most comprehensive education approach designed to ensure that every student has access to the best and highest quality educational content and equality of opportunity in education (FATİH, 2019). Fatih Project is a digitization project that employs smartboards and tablets to support education, while going even further by establishing an EBA network, adopting cloud computing tools, and assigning a digital identity for the students. Within the project, also educational e-content was developed; thus, it could be considered a digitalization step (Y1lmaz,2020). E-content has been developed for use in the FATIH Project and the employment of digital education platforms, which became an indispensable part of the learning and teaching processes, became popular. Platforms are important instruments in meeting the requirements of innovative instruction (Homanova and Prextova, 2017). Digital education platforms include educational software with animated lectures, worksheets, question solving videos, topical tests, educational games, and electronic books designed to support the students and teachers in class. In our country, the most preferred education platforms are EBA, Morpa Campus and Okulistik. EBA; It is a free digital education platform that not only offers different, rich and educational content, but also allows teachers and students to share content, besides it includes students with different learning styles (verbal, visual, numerical, social, individual, auditory learning) and tries to ensure equality of opportunity in education (FATIH,2020). Morpa Kampüs is a paid digital education platform that has been prepared to support primary school students and teachers in their lessons, where teachers can share content with students and group teachers, where teachers, parents and school administrators can monitor student progress, and where there are many modules and content suitable for the MEB curriculum. (Morpa, 2014). Okulistik is a digital education platform that has been prepared to support primary school students and teachers in lessons, contains animated lectures, worksheets, question-solving videos, subject tests, educational games, and electronic books, and it offers free services to teachers in accordance with the MEB curriculum and paid services to students (Okulistik, 2020). Due to the simple interface of the platforms, students could easily access in-depth content on any subject, participate in activities, repeat classes, and learn while having fun with educational games. Furthermore, these platforms help learning abstract topics by materializing the abstract concepts using animations. Dienes reported that mathematics could be a difficult course to learn since it includes generalizations and abstract concepts (Sar1,2015). Since digital platforms concretize the topics in courses that include abstract concepts such as the mathematics course, they ensure the comprehension of these topics by especially primary school students and could lead to permanent learning. Furthermore, these platforms gradually advance and their popularity increase due to their appeal to all human senses and provide the students practice opportunities (Kuşak, 2014). In the current age of digital learning environments and students, it is necessary to take advantage of digital education platforms in learning and instruction. Born into a digital world, the modern children, known as digital natives or the $\mathrm{Z}$ generation, expect that learning is consistent with the world mentally and physically, and they want to learn what they want due to the available 
digital tools (Seemiller and Grace, 2016).

Among various dimensions, the most important element of the platforms that affect the learning and instruction processes is e-content. Similarly, one of the five important elements of the FATIH Project was the provision and administration of educational e-content (FATIH,2019). A platform with inadequate content could not contribute to the learning and instruction processes. Another important element is motivation. Various factors affect human behavior; however, the most important factor that determines the direction, rigor and stability of behavior is motivation (Fidan, 1996). Platforms that could motivate students or improve their motivation are one step ahead of the others. The other important elements are the technique and design. The design of the platform should be adequate for the student level and easily accessible. During the period when face-to-face education was suspended and distance education was adopted due to the Covid-19 pandemic, the education and instruction processes could only be conducted on these platforms. Thus, the competency of the teachers in these platforms and their efficiency in using these platforms were important. Digital education platforms play a key role in contemporary learning and instruction processes. Thus, the analysis of different dimensions of the efficiency levels of digital education platforms is of critical importance. The literature review revealed that the analyses were conducted on a single platform in most studies. The analysis of the impact of a single platform on the learning and instruction processes in digital age could be insufficient in reflecting the impact of digital education platforms on education. It could be suggested that the analysis of various dimensions of different platforms could yield more comprehensive findings in a world where the significance of the digital education platforms have increased due to the Covid-19 pandemic. Thus, the present study aimed to investigate the efficiency of several platforms based on teacher competency, content, motivation, and design, and to determine their shortcomings and effects on the learning and instruction processes. This study is considered important since it aimed to reveal the efficiency of digital education platforms.

\section{The Aim of the Study}

The present study aimed to determine the efficiency of digital education platforms employed in mathematics courses instructed by classroom teachers based on various variables. For this purpose, the differences between the views of the classroom teachers on the sub-dimensions of the Digital Education Platform Evaluation Scale (DEPES) were determined based on the following variables:

(1) Gender,

(2) Seniority,

(3) Age,

(4) Education level,

(5) Grade of instruction,

(6) School type,

(7) In-service training.

\section{Method}

\section{The Research Model}

The study was designed in the survey model. Survey research is the collection of quantitative data through questions formed around a problem from a representative group of 
the universe and the answers given to them (Check \& Schutt, 2012). In the survey model, it is aimed to describe the researched subject without changing its existing position (Karasar, 2005). Survey research can be designed in two ways as cross-sectional and longitudinal (Creswell, 2012; Fraenkel \& Wallen, 2009).

\section{The Study Group}

The study sample included 601 classroom teachers employed in public and private primary schools in Istanbul during the 2020-2021 academic year. Teachers participating in the study, $82.5 \%$ were female, $17.5 \%$ were male, $31.6 \%$ (0-10) years, $29.5 \%$ (11-20) years, $29.3 \%$ ( 21-30) years, 9.7\% (30 years and above) have professional seniority, 22\% (22-29) age range, $27.8 \%$ (30-39) age range, $29 \%$ 0.6\% (40-49) years old, $17.3 \%$ (50-59) years old, $3.3 \%$ (60 and over) years old, $5.7 \%$ associate degree, $82.5 \%$ of them were undergraduate, $11.8 \%$ were graduates, $19.1 \%$ were first grade teachers, $25.6 \%$ were second grade teachers, $25.1 \%$ were third grade teachers. and $30.1 \%$ are 4 th grade teachers, $83.4 \%$ work in a public school, $16.6 \%$ work in a private school, $30 \%$ receive in-service training and $70 \%$ do not receive in-service training. Among the teachers participating in the research, those who use only one platform in their lessons mostly prefer EBA, the teachers who use two platforms in their lessons prefer Okulistik besides EBA, and the teachers who use three platforms in their lessons mostly prefer Morpa Campus besides EBA and Okulistik. Teachers mostly use live lessons, lessons, studies, assessment and evaluation, educational games, and professional development modules of the platforms.

\section{Data Collection Instrument}

The study data were collected with the Digital Education Platform Evaluation Scale (DEPES) developed by Özerbaş \& Yazıcı (2021). The first section of the scale includes 9 items on participant demographics, and the second section includes 20 5-point Likert type questions. The scale aims to determine the levels of participant agreement with the items and the participants select between the following responses: "Never (1)", "Rarely (2)", "Sometimes (3)", "Usually (4)" and "Always (5)." The exploratory factor analysis revealed four sub-dimensions and the Cronbach's Alpha reliability coefficients of these dimensions were $.88, .89, .75$ and .70 , respectively. These sub-dimensions explained $65.92 \%$ of the total variance. The Cronbach Alpha reliability coefficients for the scale factors were .88 for the "Teacher Competency" dimension, .89 for the "Content" dimension, .75 for the "Material Design" dimension, and .70 for the "Motivation" dimension. The factor load of the twenty scale items was above .48. The confirmatory factor analysis revealed the following results: RMSEA $=0.056 ; \chi 2 / \mathrm{sd}=2.19 ; \mathrm{SRMR}=0.051 ; \mathrm{NFI}=0.90 ; \mathrm{NNFI}=0.91 ; \mathrm{CFI}=0.93 ; \mathrm{GFI}=0.82 ;$ AGFI $=0.80 ; \mathrm{IFI}=0.91 ; \mathrm{RFI}=0.90$. The Cronbach Alpha reliability coefficient for the entire 20item scale was.92.

\section{Data Collection}

The Digital Education Platforms Evaluation Scale (DEPES) was applied to 601 primary school teachers after the Ministry of National Education approval. Due to the Covid19 pandemic, the scale was applied online to reach a higher number of teachers. The data were collected from only voluntarily participating teachers. 


\section{Data Analysis}

SPSS 23 statistics software was employed in the analysis of the study data. In data analysis, initially, the normal distribution of the data was tested to determine which parametric or non-parametric tests should be used. For this purpose, the Shapiro-Wilk test was applied, and it was determined that the result was significant $(\mathrm{p}<.05)$. Furthermore, the kurtosis and skewness of the data were determined. It was found that the kurtosis of the study data was -1.10 and the skewness was 6.73; thus, it was determined that the study data did not exhibit normal distribution. Thus, non-parametric tests were employed in data analysis. The differences between the paired variables were tested with the Mann-Whitney U-test, and Kruskal-Wallis test was used to determine the differences between the other variables.

\section{Findings}

The descriptive data of the study, which aims to examine the efficiency levels of digital education platforms used in mathematics lessons of primary school teachers in terms of different variables, are shown in tables below. According to the gender variable, the findings regarding the opinions of the classroom teachers about the sub-dimensions of the scale of the efficiency levels of the digital education platforms used in the mathematics lesson are given in Table 1.

Table 1. Results of Mann-Whitney-U Test Implemented by Gender Variable

\begin{tabular}{|c|c|c|c|c|c|c|c|}
\hline & $\begin{array}{l}\text { Sub- } \\
\text { dimensions }\end{array}$ & Gender & $\mathbf{N}$ & Mean Rank & Total Rank & $\mathbf{U}$ & $\mathbf{p}$ \\
\hline \multirow{8}{*}{ 兵 } & \multirow{2}{*}{$\begin{array}{l}\text { Teacher } \\
\text { competency }\end{array}$} & Female & 492 & 296.18 & 145721,0 & \multirow[t]{2}{*}{24443,00} & \multirow[t]{2}{*}{.471} \\
\hline & & Male & 104 & 309.47 & 32185.00 & & \\
\hline & \multirow[t]{2}{*}{ Content } & Female & 496 & 299.58 & 148593,0 & \multirow[t]{2}{*}{25337,00} & \multirow[t]{2}{*}{.661} \\
\hline & & Male & 105 & 307.70 & 32308.00 & & \\
\hline & \multirow[t]{2}{*}{ Design } & Female & 496 & 300.91 & 149251,5 & \multirow[t]{2}{*}{25995,50} & \multirow[t]{2}{*}{.978} \\
\hline & & Male & 105 & 301.42 & 31649.50 & & \\
\hline & \multirow[t]{2}{*}{ Motivation } & Female & 495 & 294.41 & 145732,0 & \multirow[t]{2}{*}{22972,00} & \multirow[t]{2}{*}{.079} \\
\hline & & Male & 104 & 326.62 & 33968.00 & & \\
\hline \multirow{8}{*}{ 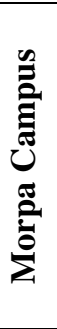 } & \multirow{2}{*}{$\begin{array}{l}\text { Teacher } \\
\text { competency }\end{array}$} & Female & 453 & 282.01 & 127751,5 & \multirow[t]{2}{*}{19020,50} & \multirow[t]{2}{*}{.037} \\
\hline & & Male & 97 & 245.09 & 23773.50 & & \\
\hline & \multirow[t]{2}{*}{ Content } & Female & 452 & 274.11 & 123895,5 & \multirow[t]{2}{*}{21517,50} & \multirow[t]{2}{*}{.773} \\
\hline & & Male & 97 & 279.17 & 27079.50 & & \\
\hline & \multirow[t]{2}{*}{ Design } & Female & 454 & 282.81 & 128397,0 & \multirow[t]{2}{*}{18926,00} & \multirow[t]{2}{*}{.026} \\
\hline & & Male & 97 & 244.11 & 23679.00 & & \\
\hline & \multirow[t]{2}{*}{ Motivation } & Female & 454 & 277.93 & 126182,0 & \multirow[t]{2}{*}{21141,00} & \multirow[t]{2}{*}{.535} \\
\hline & & Male & 97 & 266.95 & 25894.00 & & \\
\hline \multirow{8}{*}{ 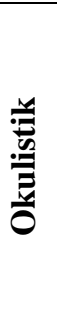 } & \multirow{2}{*}{$\begin{array}{l}\text { Teacher } \\
\text { competency }\end{array}$} & Female & 448 & 272.47 & 122067,5 & \multirow[t]{2}{*}{21491,50} & \multirow[t]{2}{*}{.993} \\
\hline & & Male & 96 & 272.63 & 26172.50 & & \\
\hline & \multirow[t]{2}{*}{ Content } & Female & 448 & 276.26 & 123766,5 & \multirow[t]{2}{*}{19369,50} & \multirow[t]{2}{*}{.165} \\
\hline & & Male & 95 & 251.89 & 23929.50 & & \\
\hline & Design & Female & 448 & 268.88 & 102460,0 & 19884,00 & .238 \\
\hline & & Male & 96 & 289.38 & 27780.00 & & \\
\hline & Motivation & Female & 448 & 276.37 & 123813,0 & 19771,00 & .212 \\
\hline & & Male & 96 & 254.45 & 24427.00 & & \\
\hline
\end{tabular}

As seen in Table 1, there was no significant difference (p>.05) between the EBA subdimensions based on the gender variable. The views of classroom teachers on all EBA subdimensions were similar based on the gender variable. It was observed that there was a difference between the perceptions about the teacher competence and design sub-dimensions of the Morpa Campus platform based on the gender $(\mathrm{p}<.05)$. In the teacher efficiency dimension of the Morpa Campus, it was observed that female teachers employed the platform more efficiently, had more knowledge and skills, and ensured that the students used the 
platform more when compared to male teachers in the mathematics course. In the design subdimension, female teachers adopted a more positive views, liked the design of the platform more, and considered it easy to use when compared to male teachers. It was determined that there was no significant difference between other Morpa Campus sub-dimension scores based on gender ( $p>.05)$. No significant difference ( $p>.05)$ was determined between the subdimensions of Okulistik platform based on the gender variable. The views of both male and female classroom teachers were similar on all sub-dimensions of Okulistik platform. According to the Seniority Variable, the Findings Regarding the Opinions of the Classroom Teachers about the Sub-Dimensions of the scale of the Sufficiency Levels of the Digital Education Platforms Used in the Mathematics Lesson are given in Table 2.

Table 2. Results of Kruskal-Wallis Test According to the Seniority Variable

\begin{tabular}{|c|c|c|c|c|c|c|c|}
\hline & $\begin{array}{l}\text { Sub- } \\
\text { dimension }\end{array}$ & $\begin{array}{l}\text { Seniorit } \\
\mathbf{y}\end{array}$ & $\mathbf{N}$ & Mean Rank & SD & $X^{2}$ & $\mathbf{p}$ \\
\hline \multirow{4}{*}{$\underset{\mathbf{c}}{\overleftarrow{x}}$} & $\begin{array}{l}\text { Teacher } \\
\text { competency }\end{array}$ & $\begin{array}{l}0-10 \\
11-20 \\
21-30 \\
31+\end{array}$ & $\begin{array}{l}189 \\
177 \\
173 \\
57\end{array}$ & $\begin{array}{l}269.28 \\
306.02 \\
311.28 \\
333.25\end{array}$ & 3 & 9.204 & .027 \\
\hline & Content & $\begin{array}{l}0-10 \\
11-20 \\
21-30 \\
31+ \\
\end{array}$ & $\begin{array}{l}190 \\
177 \\
176 \\
58 \\
\end{array}$ & $\begin{array}{l}252.59 \\
296.58 \\
340.73 \\
352.52 \\
\end{array}$ & 3 & 29.725 & .000 \\
\hline & Design & $\begin{array}{l}0-10 \\
11-20 \\
21-30 \\
31+ \\
\end{array}$ & $\begin{array}{l}190 \\
177 \\
176 \\
58\end{array}$ & $\begin{array}{l}286.94 \\
301.03 \\
301.89 \\
344.28\end{array}$ & 3 & 5.018 & .170 \\
\hline & Motivation & $\begin{array}{l}0-10 \\
11-20 \\
21-30 \\
31+ \\
\end{array}$ & $\begin{array}{l}190 \\
177 \\
175 \\
57\end{array}$ & $\begin{array}{l}270.52 \\
310.25 \\
302.19 \\
359.72\end{array}$ & 3 & 13.430 & .004 \\
\hline \multirow{4}{*}{ 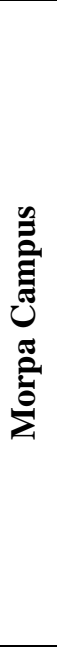 } & $\begin{array}{l}\text { Teacher } \\
\text { competency }\end{array}$ & $\begin{array}{l}0-10 \\
11-20 \\
21-30 \\
31+ \\
\end{array}$ & $\begin{array}{l}187 \\
156 \\
158 \\
49 \\
\end{array}$ & $\begin{array}{l}276.73 \\
274.40 \\
278.14 \\
265.81 \\
\end{array}$ & 3 & .246 & .970 \\
\hline & Content & $\begin{array}{l}0-10 \\
11-20 \\
21-30 \\
31+ \\
\end{array}$ & $\begin{array}{l}187 \\
156 \\
158 \\
48 \\
\end{array}$ & $\begin{array}{l}260.59 \\
275.25 \\
289.31 \\
283.21 \\
\end{array}$ & 3 & 3.018 & .389 \\
\hline & Design & $\begin{array}{l}0-10 \\
11-20 \\
21-30 \\
31+ \\
\end{array}$ & $\begin{array}{l}187 \\
156 \\
159 \\
49 \\
\end{array}$ & $\begin{array}{l}287.49 \\
273.17 \\
267.52 \\
268.67 \\
\end{array}$ & 3 & 1.667 & .644 \\
\hline & Motivation & $\begin{array}{l}0-10 \\
11-20 \\
21-30 \\
31+ \\
\end{array}$ & $\begin{array}{l}187 \\
156 \\
159 \\
49 \\
\end{array}$ & $\begin{array}{l}289.98 \\
282.45 \\
255.97 \\
267.12 \\
\end{array}$ & 3 & 4.419 & .220 \\
\hline \multirow{3}{*}{ 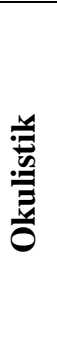 } & $\begin{array}{l}\text { Teacher } \\
\text { competency }\end{array}$ & $\begin{array}{l}0-10 \\
11-20 \\
21-30 \\
31+ \\
\end{array}$ & $\begin{array}{l}185 \\
155 \\
155 \\
49\end{array}$ & $\begin{array}{l}295.75 \\
279.55 \\
253.54 \\
222.42\end{array}$ & 3 & 11.678 & .009 \\
\hline & Content & $\begin{array}{l}0-10 \\
11-20 \\
21-30 \\
31+ \\
\end{array}$ & $\begin{array}{l}185 \\
154 \\
155 \\
49\end{array}$ & $\begin{array}{l}274.49 \\
272.23 \\
271.06 \\
264.08 \\
\end{array}$ & 3 & .188 & .979 \\
\hline & Design & $0-10$ & 185 & 258.46 & 3 & 3.440 & .329 \\
\hline
\end{tabular}




\begin{tabular}{lllllll}
\hline & $11-20$ & 155 & 270.10 & & & \\
& $21-30$ & 155 & 285.61 & & & \\
& $31+$ & 49 & 291.63 & & \\
\cline { 2 - 6 } Motivation & $0-10$ & 185 & 274.61 & & \\
& $11-20$ & 155 & 278.16 & & \\
& $21-30$ & 155 & 263.96 & & \\
& $31+$ & 49 & 273.63 & & \\
\hline
\end{tabular}

As seen in Table 2, there was a significant difference $(\mathrm{p}<.05)$ between the teacher competency, content, and motivation sub-dimensions in the EBA. In the teacher competency sub-dimension, the competency levels of the classroom teachers in a higher seniority group were higher when compared to those in lower seniority groups. The classroom teachers with higher seniority utilized the EBA platform more actively in the mathematics course, had more knowledge and skills in the platform, and ensured that the students used the platform more when compared to teachers in lower competence groups. Similarly, in the content subdimension, the views of the teachers in higher seniority groups were more positive when compared to those in lower seniority groups. The classroom teachers with higher seniority liked the EBA content more, considered it adequate and suitable for the student level and achievements when compared to those with lower seniority. In the motivation sub-dimension, the views of the teachers in higher seniority groups were more positive when compared to those in lower seniority groups. It could be suggested that the classroom teachers with higher seniority believed that EBA motivated the students more, the classes were more fun, the platform content raised students' interest and reduced their course anxiety when compared to classroom teachers with lower seniority. No significant difference ( $p>.05)$ was determined in the design sub-dimension of the EBA based on the seniority. The analysis of the views on the Morpa Campus platform revealed no significant difference ( $p>.05)$ between the scale subdimensions based on seniority variable. The views of the classroom teachers on Morpa Campus were similar in all scale sub-dimensions. It was determined that there was a significant difference only between the teacher efficiency level sub-dimension scores of the teachers for the Okulistik platform $(\mathrm{p}<.05)$. The classroom teachers in lower seniority groups employed the platform more efficiently when compared to those in higher competency groups. It was observed that the classroom teachers with lower seniority employed the platform more actively in the mathematics course, had more knowledge and skills in the platform, and ensured the employment of the platform by the students more when compared to the classroom teachers with more seniority. No significant difference ( $p>.05)$ was determined between the other sub-dimensions scores for the Okulistik platform based on the seniority variable. According to the age variable, the findings regarding the opinions of the classroom teachers about the sub-dimensions of the scale of the efficiency levels of the digital education platforms used in the mathematics lesson are given in Table 3.

Table 3. Results of Kruskal-Wallis Test for Age Variable

\begin{tabular}{|c|c|c|c|c|c|c|c|}
\hline & Sub-dimension & Age & $\mathbf{N}$ & Mean rank & SD & $\mathbf{X}^{2}$ & $\mathbf{p}$ \\
\hline \multirow{3}{*}{ 堛 } & $\begin{array}{l}\text { Teacher } \\
\text { competency }\end{array}$ & $\begin{array}{l}22-29 \\
30-39 \\
40-49 \\
50-59 \\
60+\end{array}$ & $\begin{array}{l}131 \\
167 \\
177 \\
102 \\
19\end{array}$ & $\begin{array}{l}270.75 \\
304.11 \\
302.64 \\
312.17 \\
328.53\end{array}$ & 4 & 4.982 & .289 \\
\hline & Content & $\begin{array}{l}22-29 \\
30-39 \\
40-49 \\
50-59 \\
60+\end{array}$ & $\begin{array}{l}132 \\
167 \\
178 \\
104 \\
20\end{array}$ & $\begin{array}{l}258.55 \\
280.46 \\
319.36 \\
350.20 \\
333.38\end{array}$ & 4 & 21.639 & .000 \\
\hline & Design & $22-29$ & 132 & 300.48 & 4 & 5.008 & .287 \\
\hline
\end{tabular}




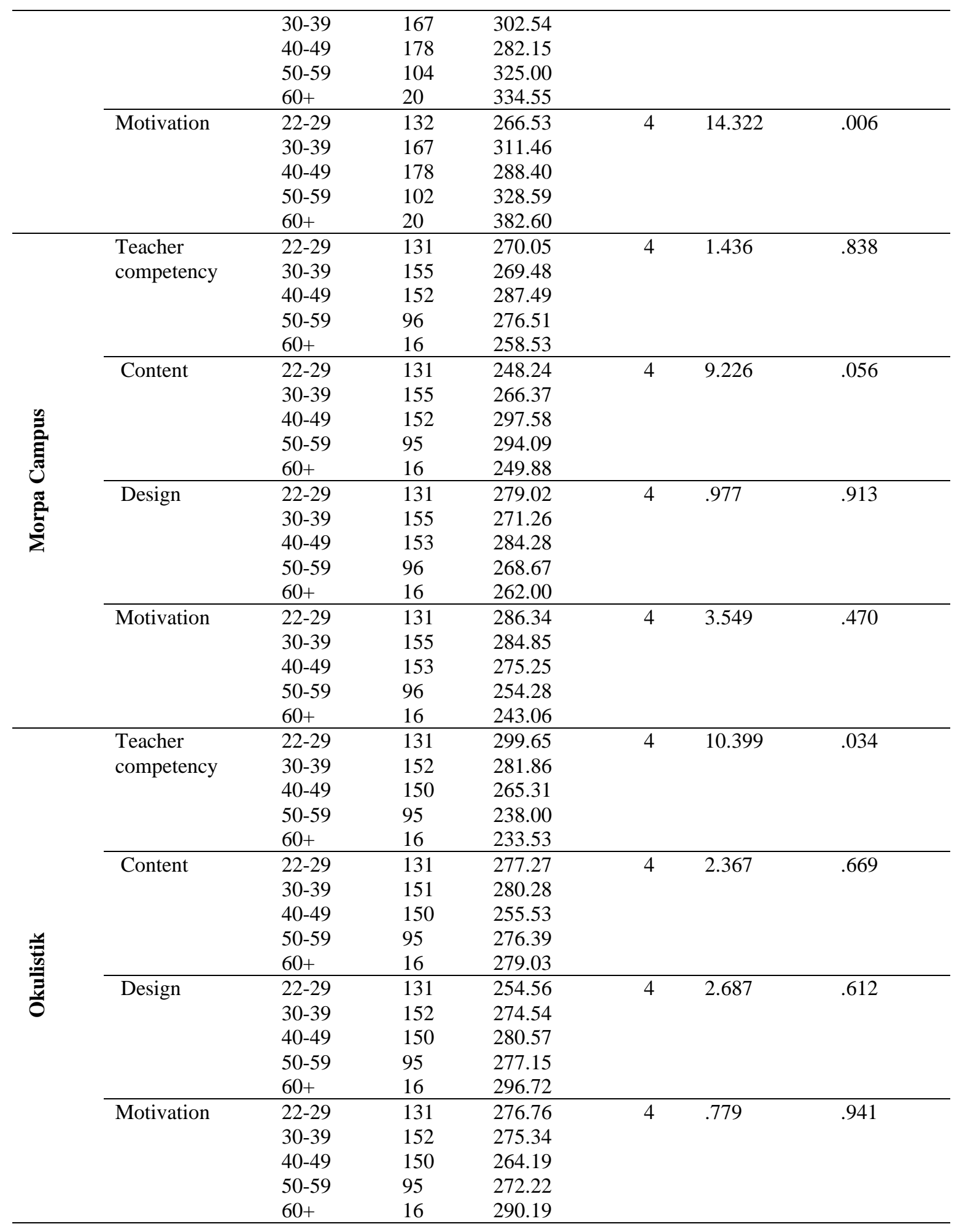

As seen in Table 3, there was a significant difference $(\mathrm{p}<.05)$ between the content and motivation scale sub-dimension scores for EBA. In the content sub-dimension, the teachers in the 50-59 age group adapted better views on EBA when compared to all other age groups, while the views of the teachers in the 60 and older age group were more positive when compared to all other age groups except the 50-59 age group, the views of the teachers in the 40-49 age group were more positive when compared to those in 22-29 and 30-39 age groups, and the views of the teachers in the 30-39 age group were more positive when compared to 
those in 22-29 age group. In general, older teachers liked the EBA content more, considered it adequate and suitable for the student level and achievements when compared to younger teachers. In the motivation sub-dimension, the views of the teachers in the 60 and older age group were more positive when compared to all other age groups, the views of the teachers in the 50-59 age group were more positive when compared to all other age groups except the 60 and older age group, the views of the teachers in the 30-39 age group were more positive when compared to those in the 22-29 and 40-49 age groups, and the views of the teachers in the 40-49 age group were more positive when compared to those in the 22-29 age group. In general, older teachers believed that EBA motivated the students more, the classes were more fun, the platform content raised students' interest and reduced their course anxiety when compared to younger classroom teachers. No significant difference ( $p>.05)$ was determined between the other scale sub-dimensions based on the age variable. The analysis of the views on the Morpa Campus platform revealed no significant difference ( $p>.05)$ between the scale sub-dimensions based on the age variable. The views of the classroom teachers on Morpa Campus were similar in all scale sub-dimensions.

It was determined that there was a significant difference only between the teacher competency sub-dimension scores of the teachers for the Okulistik platform $(\mathrm{p}<.05)$. The analysis of the views in the teacher efficiency sub-dimension based on the age variable revealed the platform competency of teachers in younger age groups was higher when compared to those in older age groups. Thus, it was observed that younger teachers employed the Okulistik platform more actively in the mathematics course, had more knowledge and skills on the platform, and ensured the employment of the platform by the students more when compared to older teachers. No significant difference ( $p>.05)$ was determined between the other sub-dimension scores for the Okulistik platform based on the age variable. According to the education level variable, the findings regarding the opinions of the classroom teachers about the subdimensions of the scale of the efficiency levels of the digital education platforms used in the mathematics lesson are given in Table 4.

Table 4. Results of Kruskal-Wallis Test Implemented to Education Level Variable

\begin{tabular}{|c|c|c|c|c|c|c|c|}
\hline & Sub-dimension & Education level & $\mathbf{N}$ & Mean Rank & SD & $\mathrm{X}^{2}$ & $\mathbf{p}$ \\
\hline \multirow{4}{*}{$\underset{\mathbf{A}}{\overleftarrow{1}}$} & $\begin{array}{l}\text { Teacher } \\
\text { competency }\end{array}$ & $\begin{array}{l}\text { Associate Deg. } \\
\text { Undergraduate } \\
\text { Graduate }\end{array}$ & $\begin{array}{l}34 \\
491 \\
71\end{array}$ & $\begin{array}{l}312.34 \\
293.33 \\
327.61\end{array}$ & 2 & 2.734 & .255 \\
\hline & Content & $\begin{array}{l}\text { Associate Deg. } \\
\text { Undergraduate } \\
\text { Graduate }\end{array}$ & $\begin{array}{l}34 \\
496 \\
71 \\
\end{array}$ & $\begin{array}{l}328.60 \\
298.10 \\
308.07\end{array}$ & 2 & 1.136 & .567 \\
\hline & Design & $\begin{array}{l}\text { Associate Deg. } \\
\text { Undergraduate } \\
\text { Graduate }\end{array}$ & $\begin{array}{l}34 \\
496 \\
71\end{array}$ & $\begin{array}{l}345.18 \\
297.09 \\
307.19\end{array}$ & 2 & 2.629 & .269 \\
\hline & Motivation & $\begin{array}{l}\text { Associate Deg. } \\
\text { Undergraduate } \\
\text { Graduate }\end{array}$ & $\begin{array}{l}34 \\
494 \\
71\end{array}$ & $\begin{array}{l}363.62 \\
294.50 \\
307.77\end{array}$ & 2 & 5.430 & .066 \\
\hline \multirow{3}{*}{ 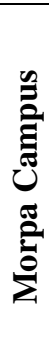 } & $\begin{array}{l}\text { Teacher } \\
\text { competency }\end{array}$ & $\begin{array}{l}\text { Associate Deg. } \\
\text { Undergraduate } \\
\text { Graduate }\end{array}$ & $\begin{array}{l}30 \\
455 \\
65 \\
\end{array}$ & $\begin{array}{l}294.88 \\
275.48 \\
266.66\end{array}$ & 2 & .651 & .722 \\
\hline & Content & $\begin{array}{l}\text { Associate Deg. } \\
\text { Undergraduate } \\
\text { Graduate }\end{array}$ & $\begin{array}{l}30 \\
455 \\
64 \\
\end{array}$ & $\begin{array}{l}289.00 \\
276.56 \\
236.03\end{array}$ & 2 & 4.561 & .102 \\
\hline & Design & $\begin{array}{l}\text { Associate Deg. } \\
\text { Undergraduate } \\
\text { Graduate }\end{array}$ & $\begin{array}{l}30 \\
456 \\
65\end{array}$ & $\begin{array}{l}299.15 \\
274.90 \\
273.01\end{array}$ & 2 & .717 & .699 \\
\hline
\end{tabular}




\begin{tabular}{|c|c|c|c|c|c|c|c|}
\hline & Motivation & $\begin{array}{l}\text { Associate Deg. } \\
\text { Undergraduate } \\
\text { Graduate }\end{array}$ & $\begin{array}{l}30 \\
456 \\
65 \\
\end{array}$ & $\begin{array}{l}258.23 \\
279.52 \\
259.53 \\
\end{array}$ & 2 & 1.308 & .520 \\
\hline \multirow{4}{*}{ 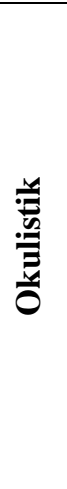 } & $\begin{array}{l}\text { Teacher } \\
\text { competency }\end{array}$ & $\begin{array}{l}\text { Associate Deg. } \\
\text { Undergraduate } \\
\text { Graduate }\end{array}$ & $\begin{array}{l}30 \\
449 \\
65\end{array}$ & $\begin{array}{l}232.57 \\
275.03 \\
273.45\end{array}$ & 2 & 2.071 & .355 \\
\hline & Content & $\begin{array}{l}\text { Associate Deg. } \\
\text { Undergraduate } \\
\text { Graduate }\end{array}$ & $\begin{array}{l}30 \\
448 \\
65 \\
\end{array}$ & $\begin{array}{l}289.12 \\
277.29 \\
227.62 \\
\end{array}$ & 2 & 6.169 & .046 \\
\hline & Design & $\begin{array}{l}\text { Associate Deg. } \\
\text { Undergraduate } \\
\text { Graduate }\end{array}$ & $\begin{array}{l}30 \\
449 \\
65 \\
\end{array}$ & \begin{tabular}{|l|}
296.85 \\
264.54 \\
316.26 \\
\end{tabular} & 2 & 7.169 & .028 \\
\hline & Motivation & $\begin{array}{l}\text { Associate Deg. } \\
\text { Undergraduate } \\
\text { Graduate }\end{array}$ & $\begin{array}{l}30 \\
449 \\
65\end{array}$ & $\begin{array}{l}289.93 \\
271.04 \\
274.55\end{array}$ & 2 & .425 & .808 \\
\hline
\end{tabular}

As seen in Table 4, there was no significant differences ( $p>.05$ ) between the teacher competence, content, design, and motivation sub-dimension scores for the EBA based on the education level of the participating teachers. The views of the classroom teachers on EBA were similar in all scale sub-dimensions based on the education level variable. There was no significant difference ( $p>.05$ ) between the teacher competence, content, design, and motivation sub-dimension scores for the Morpa Campus platform based on the education level variable. The views of the classroom teachers on the platform were similar in all scale sub-dimensions based on the education level variable. There were significant differences $(\mathrm{p}<.05)$ between the content and design sub-dimension scores for the Okulistik platform based on the education level variable. In the content sub-dimension, the views of the teachers with an associate degree were more positive when compared to those with undergraduate and graduate degrees, and the views of those with undergraduate degrees were more positive when compared to those with graduate degrees. Thus, it could be suggested that teachers with lower education levels liked the content of Okulistik platform more, considered it adequate and suitable for the student level and achievements when compared to the teachers with higher education levels. In the design sub-dimension, the teachers with graduate degrees had better ideas about the design of the platform when compared to those with associate and undergraduate degrees, and those with an associate degree had better ideas about the design of the platform when compared to those with undergraduate degrees. There was no significant difference ( $p>.05)$ between the teacher competency and motivation sub-dimension scores for Okulistik based on the educational level. According to the variable of grade level taught, the findings regarding the opinions of classroom teachers about the sub-dimensions of the scale of efficiency levels of digital education platforms used in mathematics lessons are given in Table 5.

Table 5. Results of the Kruskal-Wallis Test Implemented to Grade Level Variable

\begin{tabular}{|c|c|c|c|c|c|c|c|}
\hline & Sub-dimension & $\begin{array}{l}\text { Education } \\
\text { level }\end{array}$ & $\mathbf{N}$ & Mean Rank & SD & $\mathrm{X}^{2}$ & $\mathbf{p}$ \\
\hline \multirow{2}{*}{$\overleftrightarrow{\Delta}$} & $\begin{array}{l}\text { Teacher } \\
\text { competency }\end{array}$ & $\begin{array}{l}\text { 1st Grade } \\
\text { 2nd Grade } \\
\text { 3rd Grade } \\
\text { 4th Grade }\end{array}$ & $\begin{array}{l}114 \\
153 \\
150 \\
179\end{array}$ & $\begin{array}{l}288.31 \\
308.20 \\
273.07 \\
318.01\end{array}$ & 3 & 6.558 & .087 \\
\hline & Content & $\begin{array}{l}\text { 1st Grade } \\
\text { 2nd Grade } \\
\text { 3rd Grade } \\
\text { 4th Grade }\end{array}$ & $\begin{array}{l}115 \\
154 \\
151 \\
181\end{array}$ & $\begin{array}{l}286.77 \\
286.67 \\
282.68 \\
337.51\end{array}$ & 3 & 11.709 & .008 \\
\hline
\end{tabular}




\begin{tabular}{|c|c|c|c|c|c|c|c|}
\hline & Design & $\begin{array}{l}\text { 1st Grade } \\
\text { 2nd Grade } \\
\text { 3rd Grade } \\
\text { 4th Grade }\end{array}$ & $\begin{array}{l}115 \\
154 \\
151 \\
181 \\
\end{array}$ & $\begin{array}{l}315.64 \\
290.86 \\
273.36 \\
323.38 \\
\end{array}$ & 3 & 8.454 & .038 \\
\hline & Motivation & $\begin{array}{l}\text { 1st Grade } \\
\text { 2nd Grade } \\
\text { 3rd Grade } \\
\text { 4th Grade }\end{array}$ & $\begin{array}{l}115 \\
153 \\
151 \\
180 \\
\end{array}$ & $\begin{array}{l}281.89 \\
300.53 \\
300.00 \\
311.12 \\
\end{array}$ & 3 & 2.078 & .556 \\
\hline \multirow{4}{*}{ 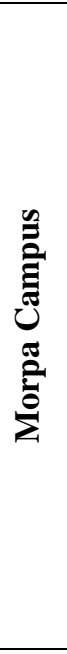 } & $\begin{array}{l}\text { Teacher } \\
\text { competency }\end{array}$ & $\begin{array}{l}\text { 1st Grade } \\
\text { 2nd Grade } \\
\text { 3rd Grade } \\
\text { 4th Grade }\end{array}$ & $\begin{array}{l}107 \\
139 \\
137 \\
167 \\
\end{array}$ & $\begin{array}{l}260.82 \\
263.59 \\
295.41 \\
278.49 \\
\end{array}$ & 3 & 3.927 & .269 \\
\hline & Content & $\begin{array}{l}\text { 1st Grade } \\
\text { 2nd Grade } \\
\text { 3rd Grade } \\
\text { 4th Grade }\end{array}$ & $\begin{array}{l}107 \\
138 \\
137 \\
167 \\
\end{array}$ & $\begin{array}{l}249.72 \\
269.17 \\
274.44 \\
296.47 \\
\end{array}$ & 3 & 6.084 & .108 \\
\hline & Design & $\begin{array}{l}\text { 1st Grade } \\
\text { 2nd Grade } \\
\text { 3rd Grade } \\
\text { 4th Grade }\end{array}$ & $\begin{array}{l}107 \\
139 \\
137 \\
168 \\
\end{array}$ & $\begin{array}{l}276.53 \\
275.02 \\
290.99 \\
264.25 \\
\end{array}$ & 3 & 2.256 & .521 \\
\hline & Motivation & $\begin{array}{l}\text { 1st Grade } \\
\text { 2nd Grade } \\
\text { 3rd Grade } \\
\text { 4th Grade }\end{array}$ & $\begin{array}{l}107 \\
139 \\
137 \\
168 \\
\end{array}$ & $\begin{array}{l}281.50 \\
274.93 \\
288.25 \\
263.40 \\
\end{array}$ & 3 & 2.023 & .568 \\
\hline \multirow{4}{*}{ 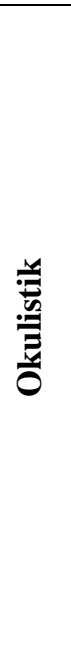 } & $\begin{array}{l}\text { Teacher } \\
\text { competency }\end{array}$ & $\begin{array}{l}\text { 1st Grade } \\
\text { 2nd Grade } \\
\text { 3rd Grade } \\
\text { 4th Grade }\end{array}$ & $\begin{array}{l}104 \\
138 \\
137 \\
165\end{array}$ & $\begin{array}{l}272.34 \\
282.79 \\
261.57 \\
273.07 \\
\end{array}$ & 3 & 1.265 & .737 \\
\hline & Content & $\begin{array}{l}\text { 1st Grade } \\
\text { 2nd Grade } \\
\text { 3rd Grade } \\
\text { 4th Grade }\end{array}$ & $\begin{array}{l}104 \\
138 \\
136 \\
165 \\
\end{array}$ & $\begin{array}{l}261.19 \\
281.84 \\
279.78 \\
264.17 \\
\end{array}$ & 3 & 1.811 & .613 \\
\hline & Design & $\begin{array}{l}\text { 1st Grade } \\
\text { 2nd Grade } \\
\text { 3rd Grade } \\
\text { 4th Grade }\end{array}$ & $\begin{array}{l}104 \\
138 \\
137 \\
165\end{array}$ & $\begin{array}{l}274.04 \\
276.32 \\
262.70 \\
276.48 \\
\end{array}$ & 3 & .757 & .860 \\
\hline & Motivation & $\begin{array}{l}\text { 1st Grade } \\
\text { 2nd Grade } \\
\text { 3rd Grade } \\
\text { 4th Grade }\end{array}$ & $\begin{array}{l}104 \\
138 \\
137 \\
165 \\
\end{array}$ & $\begin{array}{l}257.65 \\
267.12 \\
286.59 \\
274.66 \\
\end{array}$ & 3 & 2.255 & .521 \\
\hline
\end{tabular}

As seen in Table 5, there were significant differences $(p<.05)$ between the content and design sub-dimension scores for the EBA. In the content sub-dimension, the views of the teachers who instructed fourth graders were more positive when compared to all others, the views of the teachers who instructed first graders were more positive when compared to those who instructed second and third graders, and the views of the teachers who instructed second graders were more positive when compared to those who instructed third graders, and the former group of teachers liked the EBA content more, considered it adequate and suitable for student level and achievements when compared to others. In the design sub-dimension, the views of the teachers who instructed fourth graders were more positive when compared to all others, the views of the teachers who instructed first graders were more positive when compared to those who instructed second and third graders, and the views of the teachers who instructed second graders were more positive when compared to those who instructed third graders, and the former group of teachers considered the platform more easier to use and led to active participation in the class. There were no significant differences ( $p>.05)$ between the teacher competence and motivation sub-dimension scores for the EBA based on the grade of 
instruction variable.

There were no significant differences ( $p>.05)$ between the teacher competence, content, design, and motivation sub-dimension scores for the Okulistik platform based on the grade of instruction variable. The views of the classroom teachers on the platform were similar in all scale sub-dimensions based on the grade of instruction variable. According to the school type variable, the findings regarding the opinions of the classroom teachers about the sub-dimensions of the scale of the efficiency levels of the digital education platforms used in the mathematics lesson are given in Table 6.

Table 6. Results of Mann-Whitney-U Test Implemented to School Type Variable

\begin{tabular}{|c|c|c|c|c|c|c|c|}
\hline & Sub-dimension & $\begin{array}{l}\text { School } \\
\text { Type }\end{array}$ & $\mathbf{N}$ & Mean Rank & Total Rank & $\mathbf{U}$ & $\mathbf{p}$ \\
\hline \multirow{8}{*}{$\underset{1}{\mathbb{1}}$} & \multirow{2}{*}{$\begin{array}{l}\text { Teacher } \\
\text { competency }\end{array}$} & Public & 498 & 313.64 & 156192,0 & \multirow[t]{2}{*}{16863,00} & \multirow[t]{2}{*}{.000} \\
\hline & & Private & 98 & 221.57 & 21714.00 & & \\
\hline & \multirow[t]{2}{*}{ Content } & Public & 501 & 302.91 & 151757,5 & \multirow[t]{2}{*}{24093,50} & \multirow[t]{2}{*}{.543} \\
\hline & & Private & 100 & 291.44 & 29143.50 & & \\
\hline & \multirow[t]{2}{*}{ Design } & Public & 501 & 290.93 & 145755,5 & \multirow[t]{2}{*}{20004,50} & \multirow[t]{2}{*}{.001} \\
\hline & & Private & 100 & 351.46 & 35145.50 & & \\
\hline & \multirow[t]{2}{*}{ Motivation } & Public & 499 & 293.07 & 146242,0 & \multirow[t]{2}{*}{21492,00} & \multirow[t]{2}{*}{.026} \\
\hline & & Private & 100 & 334.58 & 33458.00 & & \\
\hline \multirow{8}{*}{ 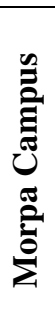 } & \multirow{2}{*}{$\begin{array}{l}\text { Teacher } \\
\text { competency }\end{array}$} & Public & 451 & 278.87 & 125772,0 & \multirow[t]{2}{*}{20803,00} & \multirow[t]{2}{*}{.287} \\
\hline & & Private & 99 & 260.13 & 25753.00 & & \\
\hline & \multirow[t]{2}{*}{ Content } & Public & 451 & 280.12 & 126335,5 & \multirow[t]{2}{*}{19788,50} & \multirow[t]{2}{*}{.101} \\
\hline & & Private & 98 & 251.42 & 24639.50 & & \\
\hline & \multirow[t]{2}{*}{ Design } & Public & 452 & 275.85 & 124686,0 & \multirow[t]{2}{*}{22308,00} & \multirow[t]{2}{*}{.962} \\
\hline & & Private & 99 & 276.67 & 27390.00 & & \\
\hline & \multirow[t]{2}{*}{ Motivation } & Public & 452 & 268.22 & 121233,5 & \multirow[t]{2}{*}{18855,50} & \multirow[t]{2}{*}{.014} \\
\hline & & Private & 99 & 311.54 & 30842.50 & & \\
\hline \multirow{8}{*}{ 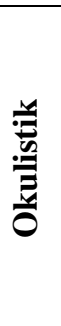 } & \multirow{2}{*}{$\begin{array}{l}\text { Teacher } \\
\text { competency }\end{array}$} & Public & 445 & 272.68 & 121343,0 & \multirow[t]{2}{*}{21947,00} & \multirow[t]{2}{*}{.954} \\
\hline & & Private & 99 & 271.69 & 26897.00 & & \\
\hline & \multirow[t]{2}{*}{ Content } & Public & 444 & 269.14 & 119498,5 & \multirow[t]{2}{*}{20708,50} & \multirow[t]{2}{*}{.364} \\
\hline & & Private & 99 & 284.82 & 28197.50 & & \\
\hline & Design & Public & 445 & 276.44 & 123015,5 & 20274,50 & .207 \\
\hline & & Private & 99 & 254.79 & 25224.50 & & \\
\hline & Motivation & Public & 445 & 267.21 & 118907,5 & 19672,50 & .094 \\
\hline & & Private & 99 & 296.29 & 29332.50 & & \\
\hline
\end{tabular}

As seen in Table 6 , there were significant differences $(\mathrm{p}<.05)$ between teacher competency, design, and motivation sub-dimension scores for the EBA. In the teacher competency subdimension, the teachers employed in public schools employed EBA more actively in the mathematics course, had more knowledge and skills about the platform, and ensured the employment of the platform by the students more when compared to classroom teachers employed in private schools. In the motivation sub-dimension, the classroom teachers employed in public schools expressed more positive views when compared to those employed in private schools. The classroom teachers employed in public schools considered that the EBA motivated the students, allowed fun in classroom, the content of the platform raised student interest and reduced course anxiety more when compared to those employed in private schools. Thus, it could be suggested that the classroom teachers employed in public schools considered that EBA motivated students more. In the design sub-dimension, the classroom teachers employed in private schools liked the design of EBA, expressed more positive views, considered it easier to use and promoted active participation in the class more when compared to classroom teachers employed in public schools. There was no significant difference ( $p>.05$ ) between the content sub-dimension scores for EBA based on the school type variable. For Morpa Campus, on the other hand, it was determined that there was a 
significant difference only between the motivation sub-dimension scores $(p<.05)$. In the motivation sub-dimension, the views of the classroom teachers employed in private schools were more positive when compared to the classroom teachers employed in public schools. It could be suggested that the classroom teachers employed in private schools believed that Morpa Campus motivated students more, led to more fun in the classroom, and the platform contents raised the interest of the students and reduced course anxiety. Thus, classroom teachers employed in private schools could prefer Morpa Campus in the mathematics course. In the other sub-dimension scores for the Morpa Campus, there were no significant differences ( $p>.05)$ based on the school type variable. There were no significant differences ( $p$.05) between the sub-dimension scores for the Okulistik platform based on the school type variable. The views of the classroom teachers on the platform were similar in all scale subdimensions based on the school type variable. According to the in-service training variable, the findings regarding the opinions of classroom teachers about the sub-dimensions of the scale of the efficiency levels of digital education platforms used in mathematics lessons are given in Table 7.

Table 7. Results of Mann-Whitney-U Test According to In-Service Training Variable

\begin{tabular}{|c|c|c|c|c|c|c|c|}
\hline & Sub-dimension & $\begin{array}{l}\text { In-Service } \\
\text { Training }\end{array}$ & $\mathbf{N}$ & Mean Rank & Total Rank & $\mathbf{U}$ & $\mathbf{p}$ \\
\hline \multirow{8}{*}{ 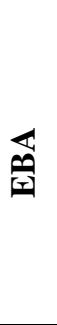 } & \multirow{2}{*}{$\begin{array}{l}\text { Teacher } \\
\text { competency }\end{array}$} & Yes & 179 & 317.68 & 56864.50 & \multirow[t]{2}{*}{33888,50} & \multirow[t]{2}{*}{.073} \\
\hline & & No & 417 & 290.27 & 121041,5 & & \\
\hline & \multirow[t]{2}{*}{ Content } & Yes & 180 & 326.24 & 58723.00 & \multirow[t]{2}{*}{33347,00} & \multirow[t]{2}{*}{.019} \\
\hline & & No & 421 & 290.21 & 122178,0 & & \\
\hline & \multirow[t]{2}{*}{ Design } & Yes & 180 & 318.81 & 57386.00 & \multirow[t]{2}{*}{34684,00} & \multirow[t]{2}{*}{.095 } \\
\hline & & No & 421 & 293.38 & 123515,0 & & \\
\hline & \multirow[t]{2}{*}{ Motivation } & Yes & 180 & 330.01 & 59401.50 & \multirow[t]{2}{*}{32308,50} & \multirow[t]{2}{*}{.005} \\
\hline & & No & 419 & 287.11 & 120298,5 & & \\
\hline \multirow{8}{*}{ 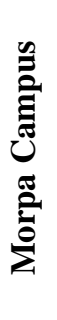 } & \multirow{2}{*}{$\begin{array}{l}\text { Teacher } \\
\text { competency }\end{array}$} & Yes & 161 & 286.57 & 46138.00 & \multirow[t]{2}{*}{29532,00} & \multirow[t]{2}{*}{292} \\
\hline & & No & 389 & 270.92 & 105387,0 & & \\
\hline & \multirow[t]{2}{*}{ Content } & Yes & 160 & 277.13 & 44340.50 & \multirow[t]{2}{*}{30779,50} & \multirow[t]{2}{*}{.839} \\
\hline & & No & 389 & 274.12 & 106634,5 & & \\
\hline & \multirow[t]{2}{*}{ Design } & Yes & 161 & 287.83 & 46340.50 & \multirow[t]{2}{*}{29490,50} & \multirow[t]{2}{*}{.250} \\
\hline & & No & 390 & 271.45 & 105735,5 & & \\
\hline & \multirow[t]{2}{*}{ Motivation } & Yes & 161 & 287.03 & 46211.50 & \multirow[t]{2}{*}{29619,50} & \multirow[t]{2}{*}{.293} \\
\hline & & No & 390 & 271.45 & 105864,5 & & \\
\hline \multirow{8}{*}{ 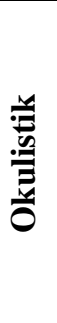 } & \multirow{2}{*}{$\begin{array}{l}\text { Teacher } \\
\text { competency }\end{array}$} & Yes & 159 & 276.07 & 43895.00 & \multirow[t]{2}{*}{30040,00} & \multirow[t]{2}{*}{.733} \\
\hline & & No & 385 & 271.03 & 104345,0 & & \\
\hline & \multirow[t]{2}{*}{ Content } & Yes & 158 & 287.50 & 45425.00 & \multirow[t]{2}{*}{27966,00} & \multirow[t]{2}{*}{.137} \\
\hline & & No & 385 & 265.64 & 102271,0 & & \\
\hline & Design & Yes & 159 & 258.69 & 41132.00 & 28412,00 & .180 \\
\hline & & No & 385 & 278.20 & 107108,0 & & \\
\hline & Motivation & Yes & 159 & 300.61 & 47797.50 & 26137,50 & .007 \\
\hline & & No & 385 & 260.89 & 100442,5 & & \\
\hline
\end{tabular}

As seen in Table 7, there were significant differences $(\mathrm{p}<.05)$ between the content and motivation scale sub-dimension scores for the EBA. It could be suggested that the classroom teachers who received in-service training liked the EBA content, considered it adequate and suitable for the student level and achievements more when compared to the classroom teachers who did not receive in-service training. It was determined that the views of the classroom teachers who received in-service training on the motivation sub-dimension were more positive when compared to the classroom teachers who did not receive in-service training. Thus, the classroom teachers who received in-service training considered that the EBA motivated students more, led to more fun in the classroom, the platform content was more interesting for the students, and reduced course anxiety when compared to classroom 
teachers who did not receive in-service training. There was no significant difference $(p>.05)$ between teacher competency and design sub-dimension scores for EBA based on the inservice training variable. The fact that there was no significant difference between the efficiency levels of the classroom teachers based on the in-service training variable could suggested that the classroom teachers were not provided quality in-service training on the employment of the platform.

There were no significant differences $(p>.05)$ between the sub-dimension scores for the Morpa Campus platform based on the in-service training variable. The views of the classroom teachers on the platform were similar in all scale sub-dimensions based on the in-service training variable. Thus, it could be suggested that this was due to the lack of in-service training on Mopa Campus. It was determined that there was a significant difference between the motivation sub-dimension scores for the Okulistik platform $(\mathrm{p}<.05)$. In the motivation sub-dimension, it was determined that the views of the teachers who received in-service training were more positive when compared to those of the teachers who did not receive inservice training. Similarly, it could be suggested that the classroom teachers who received inservice training considered that Okulistik motivated students, led to fun in the classroom more, the platform content raised the interest of the student, and reduced course anxiety more when compared to classroom teachers who did not receive in-service training. There were no significant differences between other sub-dimension scores for the platform based on the inservice training variable $(\mathrm{p}>.05)$.

\section{Discussion and Conclusion}

In this study, it is aimed to examine the efficiency levels of the classroom teachers on the digital education platforms used in the mathematics in terms of different variables. The sample group of the study included variables of classroom teachers such as (Gender, Seniority Year, Age, Education Level, Class Instructed, Type of school they work in, and In-service training status) working in private and public primary schools in Istanbul in the 2020-2021 academic year. The data are limited to the answers given to the questions in the scale applied to the teachers. The findings obtained through the research are given below in reply to the purpose of the study.

When the opinions of the classroom teachers were examined according to the gender variable, there were no significant difference in the sub-dimensions of EBA and Okulistik. In this situation, there was parallelism with the results of the studies of Campbell, (2001) and Lyons (2012) encountered in the literature. In addition, with respect to Uzundağ (2016)'s study, there was no differentiation on the gender variable of teachers' platform use situations. Similarly, in the studies of Ceylan (2019) and Kalemkuss (2016), there was no significant difference in the EBA use of men and women. However, in the same study, it was observed that there was a difference for Morpa Campus on sub-dimension of the teacher efficiency level and design according to the gender variable. When it was analyzed the classroom teachers on the dimension of teacher efficiency level of the Morpa Campus, female teachers, compared to male teachers, have used the platform more actively in mathematics lessons, have more knowledge and skills about the platform, and direct students to the platform more. On the design's sub-dimension of Morpa Campus, it was concluded that female teachers had more positive thoughts than male teachers, liked the design of the platform more and thought that it was easier to use.

According to the seniority variable, when the opinions of the classroom teachers on the sub- 
dimensions of the scale of the efficiency levels of the digital education platforms used in the mathematics lesson were examined, it was found that content and motivation sub-dimensions for the EBA platform More senior teachers had more positive views on the EBA in the teacher competency, content and motivation sub-dimensions of the scale when compared to the teachers with less seniority. It was determined that senior teachers employed the platform more actively in the mathematics course, had more knowledge and skills about the platform, and ensured the use of the platform by the students more, liked the EBA content more, considered it adequate and suitable for the student level and achievements, and considered that EBA motivated the students better, led to more fun classes, raised student interest and reduced course anxiety when compared to junior teachers. The most important of these features, it has an academic support system supported by artificial intelligence Bartlett Bragg, (2006). A significant difference was only determined between the teacher competency subdimension for the Okulistik platform. In the teacher competency sub-dimension, it was concluded that junior teachers employed the platform more actively in the mathematics course, had more knowledge and skills about the platform, and ensured the use of the platform by the students more when compared to senior teachers. Similarly, in a study conducted by Uzundağ (2016), a significant difference was reported based on the seniority variable. Ceylan (2019) reported no significant difference between the adoption levels of EBA based on professional seniority. In the present study, there were no significant differences between the scale sub-dimension scores for the Morpa Campus based on seniority. It can be concluded that teachers with more seniority use EBA the most among the platforms, and that they do not go beyond the usual patterns. It has seen as a great advantage that EBA was participated to the educational process for teachers with more seniority who see the difficulty of teaching only on the board. Because EBA make easier to the educational process.

When the opinions of the classroom teachers according to the age variable were analyzed, it was concluded that the teachers with the older age group had more positive thoughts on subdimensions of the content and motivation than the teachers with the younger age group. In general, older teachers liked the EBA content more, considered it adequate and suitable for the student level and achievements, and EBA motivated the students more, led to more fun in the classroom, raised the interest of the students, and reduced course anxiety when compared to younger teachers. It was determined that there was a significant difference only between the teacher competency sub-dimension for the Okulistik platform. The analysis of the teacher competency sub-dimension for the Okulistik based on the age variable revealed that younger teachers employed the platform better when compared to older teachers. It was concluded that younger teachers employed Okulistik more actively in the mathematics course, had more knowledge and skills about the platform, and ensured the use of the platform by the students more when compared to older teachers. In a study conducted by İşman (2002), it was concluded that the attitudes of young teachers towards technology were more positive when compared to older teachers. It was seen that digital immigrant teachers, who are weak technology use, liked EBA more, and digital native teachers, who are better technology use, liked Okulistik. From this, it is concluded that the technological content of Okulistik is more advanced than EBA.

When the views of the classroom teachers were analyzed according to the education level variable. The analysis of the views of the classroom teachers on the sub-dimensions of the scale of the efficiency of the digital education platforms employed in the mathematics course based on the education level variable revealed that there were significant differences between the content and design sub-dimension scores for the Okulistik platform based on the education level variable. It was concluded that teachers with a lower education level liked the 
content of Okulistik platform more, considered it adequate and sufficient for the student level and achievements when compared to the teachers with a higher education level. Considering the fact that teachers, who have a high level of education, do not like the content of Okulistik it can be inferred that the content of Okulistik should be improved. On the other hand, in the design sub-dimension, the views of the classroom teachers with graduate degrees were more positive when compared to the classroom teachers with associate or undergraduate degrees, and the views of the classroom teachers with associate degreed were more positive when compared to the classroom teachers with undergraduate degrees. Based on the education level variable, there were no significant differences between the scale sub-dimension scores for EBA and Morpa Campus platforms. Alabay (2015), Uzundağ (2016), and Yorganc1 (2019) reported no significant differences between the adoption of EBA by the teachers based on the education level variable. Significant differences were determined between the scale content and design sub-dimension EBA scores of the classroom teachers based on the grade level of instruction variable. In the content sub-dimension, the views of the teachers who instructed 4th graders were more positive when compared to all others, the views of the teachers who instructed 1st graders were more positive when compared to those who instructed 2 nd and 3rd graders, and the views of the teachers who instructed 2nd graders were more positive when compared to those who instructed 3rd graders, and the former groups liked the EBA content more, considered it adequate and suitable for the student level and achievements, had positive views about the design of the EBA platform, considered it easy to use, and led to active participation in the class. It was observed that the views of the teachers who instructed 4th graders were more positive on both the content and design dimensions for the EBA when compared to all other teachers. Thus, it could be concluded that the content and design of the EBA for 4th graders were better, while the content and design of the EBA for other grades were not. Akman, (2013), Kurt et al. (2013), Pamuk et al. (2013), Altın (2014), Alabay (2015), Arslan (2016), and Saklan and Ünal (2018) similarly concluded that the EBA content was inadequate. There were no significant differences between the scale sub-dimension scores for Okulistik and Morpa Campus platforms based on the grade level of instruction variable. The efficiency levels in the scale sub-dimensions were similar for both Okulistik and Morpa Campus platforms.

The analysis of the views of the classroom teachers on the scale sub-dimensions about the efficiency of the digital education platforms employed in the mathematics course based on the school type variable revealed that there were significant differences between the teacher competency, design, and motivation sub-dimension scores for the EBA. In the teacher competency and motivation sub-dimensions, it was determined that the classroom teachers employed in public schools utilized the EBA more efficiently in the mathematics course, had more knowledge and skills about the platform, and enabled the employment of the platform by the students more when compared to the classroom teachers employed in private schools, and they considered that EBA motivated the students more, led to more fun in the classroom, the platform content raised student interest and reduced course anxiety. Since EBA is a platform supported by the state, teachers employed in public schools use the platform more; and thus, possess higher qualifications. Classroom teachers employed in private schools may not prefer EBA since they consider that EBA does not motivate students in the class. In the design sub-dimension, it was concluded that classroom teachers employed in private schools liked the design of the EBA more, had more positive views, and it was easier to use when compared to the classroom teachers employed in public schools. Thus, it could be suggested that teachers employed in public schools did not like the design of EBA. In the content subdimension, there were no significant differences based on the type of school of employment. For Morpa Campus, on the other hand, it was determined that there was a significant 
difference only between the motivation sub-dimension scores based on school type. In the motivation sub-dimension, it was determined that the views of the classroom teachers employed in private schools were more positive on Morpa Campus when compared to the classroom teachers employed in public schools. It was concluded that the classroom teachers employed in private schools considered that Morpa Campus motivated the students, led to a more fun class activities, the platform content raised the student interest and reduced course anxiety. Thus, the classroom teachers employed in private schools may prefer the Morpa Campus platform in mathematics course. In other sub-dimensions, no significant differences were determined based on the school type variable. On the other hand, the analysis of the Okulistik data revealed no significant differences between any of sub-dimension scores based on the school type variable. Thus, the teachers employed in both public and private schools agreed on all scale sub-dimensions for Okulistik.

Based on the in-service training variable, the analysis of the views of the classroom teachers on scale sub-dimensions of the efficiency levels of the digital education platforms employed in the mathematics course demonstrated that there were significant differences between the content and motivation sub-dimension scores for the EBA and only between the motivation sub-dimension scores for Okulistik. It was observed that the views of the classroom teachers who received in-service training were more positive on the content and motivation subdimensions for EBA when compared to the classroom teachers who did not receive in-service training. In the study, it was determined that the classroom teachers who received in-service training liked the EBA content, considered it adequat, and suitable for the student level and achievements, and EBA motivated the students more, led to more fun in the classroom, raised the interest of the students and reduced course anxiety when compared to the classroom teachers who did not receive in-service training. In the literature supporting this result, it is known that the lack of education level on effective use of digital platforms endeangers the use of digital tools by individuals (Oyedemi, 2012). In studies conducted by Arslan (2019) and Ceylan (2019), it was concluded that the awareness of the teachers about the content and other properties of the EBA. Thus, it could be concluded that in-service training had a positive impact on teachers. The fact that there was no significant difference between the teacher competency levels of the classroom teachers based on the in-service training variable could suggest the lack of quality teacher training on the use of the platform. There was no significant difference between the sub-dimension scores for Morpa Campus based on inservice training. The lack of a special in-service training for Morpa Campus platform could be the reason for the lack of a significant difference. Especially in Turkey, in the transition to digital learning atmosphere, first of all, teachers should be adapted to this process. Because digital natives, which means individuals were born after 1990 and accustomed to technology, are teachers and for them the usage of digital platforms are much more easier (Palfrey \& Gasser, 2011). Based on the digital teacher competencies (Redecker, 2017), which are expected to be the basis for the policies and practices to be developed in the digitalization process of both in-service education and teaching environments, it can be said that all teachers undergo this process will increase the quality of education. It has been concluded that digital immigrant teachers use EBA more in their lessons, and digital native teachers use Okulistik in their lessons. From this point of view, it can be concluded that Okulistik is in advanced level than EBA in terms of technology. There are differences in the platforms used in public and private schools. In this result, EBA is a state-supported platform has been effective. In comparisons, it can be concluded that the distinctive features of Morpa Campus are not revealed. Because the platform is less preferred due to its paid nature, its features are relatively less known. In general, it was concluded that all platforms should improve their content. The fact that all grade-level content of EBA is not at the same level of efficiency also 
causes not all teachers to prefer EBA. In order for EBA to contribute more to the learning and teaching process, the content of all grade levels have to be of the same quality and at the sufficient level. In this direction, the content of EBA should be developed and enriched. At the same time, the designs of the platforms should be rearranged in a way that attracts the attention of primary school students and find easily what they are looking for. Teachers can be given qualified in-service training on platforms. In this study, the efficiency levels of digital education platforms used by classroom teachers in mathematics lessons were analyzed in terms of different variables. In future research, the views of teachers at other levels and other education stakeholders on digital education platforms can be examined. In addition, the results of this research are limited to the classroom teachers working in the province of Istanbul. More generalizable results can be obtained with studies to be conducted with teachers working in different provinces of Turkey.

\section{References}

Akman, N. (2013). FATIH (Fırsatları arttırma teknolojiyi iyileştirme hareketi) projesi'nin ögretmenler tarafindan değerlendirilmesi [Evaluation of FATIH (Movement to increase opportunities and improve technology) project by teachers]. Master Thesis, Istanbul University Institute of Science and Technology, Istanbul.

Alabay, A. (2015). Ortaöğretim öğretmenlerinin ve öğrencilerinin eba (ĕgitimde bilişim ă̆l) kullanımına ilişkin görüşleri üzerine bir araştırma [A research on the opinions of secondary school teachers and students on the use of eba (information network in education)]. Master Thesis, Istanbul Aydin University Institute of Social Sciences, Istanbul.

Albion, P. R. (2008). Web 2.0 in teacher education: Two imperatives for action. Computers in the Schools, 25(3), 181-198. https://doi.org/10.1080/07380560802368173

Altın, H. M. (2014). Öğrenci, ögrretmen, yönetici ve veli bakış açısıyla fatih projesinin incelenmesi [Examining the Fatih project from the perspective of students, teachers, administrators and parents]. Master Thesis, Başkent University Institute of Educational Sciences, Ankara.

Arslan, E. (2019). Ĕ̆itim bilişim ă̆ına ilişkin okul öncesi öğretmenlerinin görüşleri [Opinions of preschool teachers about educational information network]. Master Thesis, Recep Tayyip Erdogan University Institute of Social Sciences, Rize.

Arslan, Z. (2016). Ĕgitim bilişim ăğndaki matematik dersi içeriğine ilişkin öğretmen görüşleri: trabzon ili örneği [Teachers' views on the content of mathematics lessons in the educational information network: The case of Trabzon province]. Master Thesis, Gazi University Institute of Educational Sciences, Ankara.

Bartlett Bragg, A. (2006). Reflections on pedagogy: Reframing practice to foster informal learning with social software. Retrieved from http://matchsz.inf.elte.hu/TT/docs/Anne20Bartlett-Bragg.pdf.

Bull, G. \& Kajder, S. (2004). Digital storytelling in the language arts classroom. Learning \& Leading with Technology, 32(4), 46-49.

Büyüköztürk, Ş. (2011). Sosyal bilimler için veri analizi el kitabı (13. b.) [Data analysis handbook for social sciences (13. b.)]. Ankara: Pegem Akademi.

Büyüköztürk, Ş., Çakmak, E., Akgün, Ö.E., Karadeniz, Ş. \& Demirel, F. (2012). Eğitimde bilimsel araştırma yöntemleri [Scientific research methods in education]. Ankara: Pegem Akademi.

Cabı, E. (2015). Dijital teknolojiye yönelik tutum ölçeği [Scale of attitude towards digital technology]. Kastamonu Journal of Education, 24(3), 1229-1244. 
Campbell, D. (2001), “Can the digital divide be contained?", International labour review, 140 (2), 119-141.

Check, J. ve Schutt, R. K. (2012). Research methods in education. Boston: Sage Publications.

Creswell, J. W. (2012). Educational research: Planning, conducting and evaluating quantitative and qualitative research. Boston: Pearson Education.

Ceylan, H. (2019). Fen bilgisi öğretmenlerinin ĕgitim öğretimde, ĕgitim bilişim ă̆ından yararlanmaya ilişkin görüşleri [Views of science teachers about using educational information network in education]. Master Thesis, Trakya University Institute of Science and Technology, Edirne.

FATİH (2019). http://fatihprojesi.meb.gov.tr/ retrieved on April 11, 2021.

Garcia, P. \& Rossiter, M. (2010). Digital storytelling as narrative pedagogy. Proceedings of society for information technology \& teacher education international conference, 1091-1097.

Homanova, Z. \& Prextova, T. (2018 Kasim 30). Educational networking platforms through the eyes of czech primary school students. AIP Conference Proceedings 2040, University of Ostrava, Czech Republic City.

İşman, A. (2002). Sakarya'da görev yapan öğretmenlerin ĕgitim teknolojileri yönünden yeterlikleri [Competences of teachers working in Sakarya in terms of educational technologies]. The Turkish Online Journal of Educational Technology 1(10), 72-91.

Karasar, N. (2014). Bilimsel araştırma yöntemi: kavramlar ilkeler teknikler [Scientific research method: concepts principles techniques]. Ankara: Nobel Akademik Yayıncilik.

Kline, R. B. (2011). Principles and practice of structural equation modeling (Third ed.). New York: The Guilford Press.

Kurt, A. A., Kuzu, A., Dursun, Ö. Ö., Güllüpınar, F., \& Gültekin, M. (2013). FATİH projesinin pilot uygulama sürecinin değerlendirilmesi: ögretmen görüşleri [Evaluation of the pilot implementation process of the FATIH project: teacher opinions]. Journal of Instructional Technologies \& Teacher Education, 1(2), 1-23.

Kuşak, M. (2014). Kelime öğretimi ve teknoloji. I. S. Ertem (Ed.), Okuma yazma eğitimi ve teknoloji içinde (61-79) [Vocabulary teaching and technology. NS. In S. Ertem (Ed.), Literacy education and technology (61-79)]. Ankara: Nobel Yayıncilik.

Lyons, R. (2012). Investigating student gender and grade level differences in digital citizenship behavior. Yayımlanmamış Doktora Tezi. USA: Walden University.

Menezes, H. (2012). Using digital storytelling to improve literacy skills. Paper presented at the International Conference on Cognition and Exploratory Learning in Digital Age. Retrieved from ERIC database. (ED542821).

Morpa Kampüs (2020). https://www.morpakampus.com/kesfet accessed from the page.

Okulistik (2020). https://www.okulistik.com/anasayfa/uzaktan-egitim.html accessed from the page.

Oyedemi, T. D. (2012). The partially digital: internet, citizenship, social inequalities, and digital citizenship in South Africa.

Özerbaş, M.A. (2020). Öğretim Teknolojileri [Instructional Technologies]. Ankara: Pegem Akademi.

Özerbaş, M. A. ve Yazıc1, E. B. (2021). Dijital Ĕ̌gitim Platformu Değerlendirme Ölçeği'nin (DEPDÖ) geliştirilmesi çalışmast [Development of the Digital Education Platform Evaluation Scale (DEPDS)]. Manas Journal of Social Studies, 10(2), 901-917.

Palfrey, J. G., \& Gasser, U. (2011). Born digital: understanding the first generation of digital natives: Read How You Want. Com.

Pamuk, C., Çakır, R., Ergun, M., Yıılmaz, H.M. Özerbaş, M.A. \& Ayas, C. (2013). Öğretmen ve ögrenci bakış açısıyla tablet pc ve etkileşimli tahta kullanımı: fatih projesi 
değerlendirmesi [The use of tablet $p c$ and interactive whiteboard from the perspective of teachers and students: Evaluation of Fatih Project. Educational Sciences]. Theory \& Practice, 13(3), 1799-1822.

Redecker, C. (2017). European framework fort he digital comoetence of educators: DigcompEdu.

Ribble, M. ve Bailey, G. (2007). Digital citizenship in schools. Washington, DC: International Society for Technology in Education.

Saklan, H., Ünal, C. (2019). Dijital eğitim platformlarl arasında ebanın yeri ile ilgili fen bilimleri ögretmenlerinin görüşleri [Opinions of science teachers about the place of eban among digital education platforms]. OMÜ Journal of the Faculty of Education, 38(1), 19-34. doi:10.7822/omuefd.431247.

Sarı, M.H. (2015). Illkokul 4. sınıfta dienes ilkelerine göre yapılandırılmış geometri etkinliklerinin öğrenci başarısına, kalıcılı̆ga ve akademik benlik algisına etkisi [The effect of geometry activities structured according to dienes principles on student achievement, permanence and academic self-perception in primary school 4th grade]. Doctoral Thesis, Gazi University Institute of Educational Sciences, Ankara.

Seemiller, C., \& Grace, M. (2016). Generation Z goes to college: John Wiley \& Sons.

Tutar, M. (2015). Ĕ̆itim bilişim ăğ (eba) sitesine yönelik olarak ögretmenlerin görüşlerinin değerlendirilmesi [Evaluation of teachers' opinions about the education information network (eba) site]. Master Thesis, Karadeniz Technical University Institute of Educational Sciences, Trabzon.

Uzundağ, K. (2016). Sinıf öğretmenlerinin sanal manipülatiflere ilişkin görüşleri [Views of classroom teachers on virtual manipulatives]. Master Thesis, Adnan Menderes University Institute of Social Sciences, Aydin.

Yang, Y.-T. C. \& Wu, W.-C. I. (2012). Digital storytelling for enhancing student academic achievement, critical thinking and learning motivation: A year-long experimental study. Computers and Education, 59, 339-352.

Yılmaz, T. (2020). Öğrenme ve ögretimde dijitalleşme ve web araçları [Digitization and web tools in learning and teaching]. M. A. Özerbaş, (Ed.), in Instructional Technologies (181-214). Ankara: Pegem Akademi.

Yorganc1, F. (2019). Ortaokul matematik öğretmenlerinin ĕgitim bilişim ă̆ projesinden yararlanma düzeyleri ve proje hakkındaki görüşleri [Secondary school mathematics teachers' level of benefit from the educational information network project and their opinions about the project]. Master Thesis, Van Yüzüncü Yıl University Institute of Educational Sciences, Van. 